\title{
Informal sector housing Scenario Analysis for Chattogram, Bangladesh: A Way Forward
}

\author{
Qazi Azizul Mowla ${ }^{1 *}$ and Kanu Kumar Das ${ }^{2}$ \\ ${ }^{1}$ Professor of Urban Design, Department of Architecture, Bangladesh University of Engineering and Technology (BUET), Bangladesh
}

${ }^{2}$ Assistant Professor, Department of Architecture, Chittagong University of Engineering and Technology (CUET), Bangladesh

*Corresponding author: Qazi Azizul Mowla, Professor of Urban Design, Conservation and Landscape Division, Department of Architecture, Bangladesh University of Engineering and Technology (BUET), Bangladesh

\begin{abstract}
Population growth rate, urban migration and natural disasters are making, the chronic shortage of housing in the developing countries, more complicated and strenuous. The case of Bangladesh is no different. However, though the growth rate of Chittagong is high yet due to various infrastructural and socio-environmental issues, the people of Chittagong are facing housing shortage. In most of the cases the development of informal sector housing is makeshift, unplanned and the consideration to the geographical, environmental, and ecological matrix is minimal. People who are in the informal sector and economically disadvantaged, cannot get proper shelter due to the shortage of housing or housing ingredients for the poor. This paper attempts to find a way to mitigate the shortage of informal sector economically disadvantaged group housing within the current market scenario. A mixed income group housing subsidized for lower income category by profit sharing from other categories is recommended to make it a win-win approach.
\end{abstract}

\section{Introduction}

Bangladesh is a densely populated developing country and is facing housing shortage due to different reasons Khaled, Sultana, Biswas, \& Karan [1]. The Government and other organizations are trying to solve the housing problem on a long-term basis with various strategies. As the growth rate of Chittagong is very high, proper housing and planning is essential for its sustainable development. The aim of this paper is to propose an economically viable housing scheme for the informal sector poor people in Chittagong city, particularly for displaced landslide victims, of Bangladesh for their better and safe life.

\section{Background of the problem}

Housing refers to many issues surrounding the way in which fundamental human needs for shelter and associated needs for privacy and security are met NHA [2]. For housing, political commitment is necessary to provide easy access to housing for all, ideological issues have to be addressed by adopting a policy of equity in housing, and the institutional issue refers to the methods or institution of enabling the majority households in owning or building their houses Islam $\mathrm{N}$ [3]. The housing situation in Bangladesh suffers from malignancy. The ancillary physical, social and economic facilities and services essential for the development of healthy and harmonious community life are highly inadequate Mowla [4] Jamil \& Ahmed [5]. The unsatisfactory housing situation is further reflected in the total and per capita availability of floor space of the main living area. The average floor space per person is $3.7 \mathrm{~m} 2$. In Dhaka around 35\% of the people lived below the poverty line, out of which around $20 \%$ were classified as "hard-core poor" who lived in informal settlements Islam $N$ [6]. This situation is a reflection of other major Cities in Bangladesh.

\section{Housing scenario in Bangladesh}

According to a recent estimate, $21 \%$ of urban households (headcount ratio) were poor (of this $7.7 \%$ were very poor); a little better than the rural households, where the poverty level was $35.2 \%$ (of these $21.1 \%$ were very poor), poverty has reduced both in urban and rural Bangladesh by approximately 7\% from 2005 to 2010 (BBS-2011). Roughly $40 \%$ of low-income urban households do not 
have access to adequate housing Nawaz R [7]. In urban Bangladesh, estimated housing shortages were about 1.0 1.5 million, with about 500,000 dwelling units added annually Nenova T [8]. The average size of owner-occupied dwellings was (44.4sq.m) more than twice that of squatter dwellings (21.5sqm), while the average size of a rental dwelling was 35sq.m. The owner-occupied dwellings were large, but rental dwellings were overall of better quality. For instance, access to poor quality toilets in rental dwellings was only $21 \%$, in comparison with $34 \%$ in owner-occupied dwellings. In the same way, access to drinking water from any sources maintained by the statutory bodies/non-government organizations was $35 \%$ in rental housing stock, while only $13 \%$ in owner housing stock. Rental dwellings also had better structural qualities in comparison with owner-occupied dwellings. As expected, squatter dwellings were of the worst quality, such as small size, poor structural quality and inadequate access to urban amenities Mowla [4]; Ahmad [9]. Standardization, in the Private Residential Land Development Rule 2004 is there, which provides percentages of land that must be kept for community facilities, amount of land to be sold out, area for education, health facilities, community and market, Playground and park area, road hierarchy (It also Define the width of Right of way) and importantly planning standards, for example, allocation of land per 1000 population, but unfortunately it is not monitored.

\section{Inform sector housing scenario in chattogram at a gance}

The Chattogram Statistical Metropolitan Area (SMA) covers an area of 1,152 square kilometers and consists of six metropolitan thanas. 68 wards and 236 mohallas (localities) with a population of 3.38 million. Chittagong City Corporation covers an area of 155 square kilometers with a population of 4,009,423 in 2011, which had grown on average by 3.6\% per annum between 1991 and 2001(BBS). The population growth is much higher compared with national growth of about 1.6 percent. The garment industry has increased the number of females migrating into the city. 35 percent of the city's populations are slum dwellers IDS [10].

\section{Housing Scenario in Chittagong}

\section{Affordability}

Table1 \& 2 According to REHAB Chittagong Fair 2012-Survey Report almost $56 \%$ funding for buying flat/plot is from the personal and family savings where only $23 \%$ of the mortgage loan Table 3 .

Table 1: Budget for an Apartment Purchase.

\begin{tabular}{|c|c|c|}
\hline Budget in Tk & Frequency & Percentage \\
\hline 20-30 Laks & 0 & 0 \\
\hline 30-40 Laks & 32 & $21 \%$ \\
\hline 40-50 Laks & 79 & $53 \%$ \\
\hline 50 Laks above & 39 & $26 \%$ \\
\hline Total & 150 & $100 \%$ \\
\hline
\end{tabular}

Table 2: Source of Fund.

\begin{tabular}{|c|c|}
\hline Financial Instrument & Percentage of Funding \\
\hline Personal Saving & $31 \%$ \\
\hline Family Saving & $23 \%$ \\
\hline Foreign Remittance & $23 \%$ \\
\hline Mortage Finance & $23 \%$ \\
\hline Others (Business) & $1 \%$ \\
\hline
\end{tabular}

Table 3: Size of Apartment among Consumers.

\begin{tabular}{|c|c|c|c|}
\hline Flat size & 850to 1200sft & 1500to 1700sft & 2000+sft \\
\hline $\begin{array}{c}\text { Demand of } \\
\text { percentage }\end{array}$ & $35 \%$ & $63 \%$ & $2 \%$ \\
\hline
\end{tabular}

\section{The size of apartment}

It is important to consider because consumers budget is related to the apartment size. The minimum apartment size is $850 \mathrm{sqft}$ for the lower Income Group (LIG) where maximum size is more than 2000 sqft. But most preferable apartment size is 1250 to $1550 \mathrm{sft}$ which is almost $50 \%$ of total demand Khaled, Sultana, Biswas, \& Karan, [1]. When the apartment area increases the price also increase, though below 1000sqft is not preferable in Bangladesh context, yet for lower income and middle-income people it is within their affordable budget Table 3 \& Figure 1.

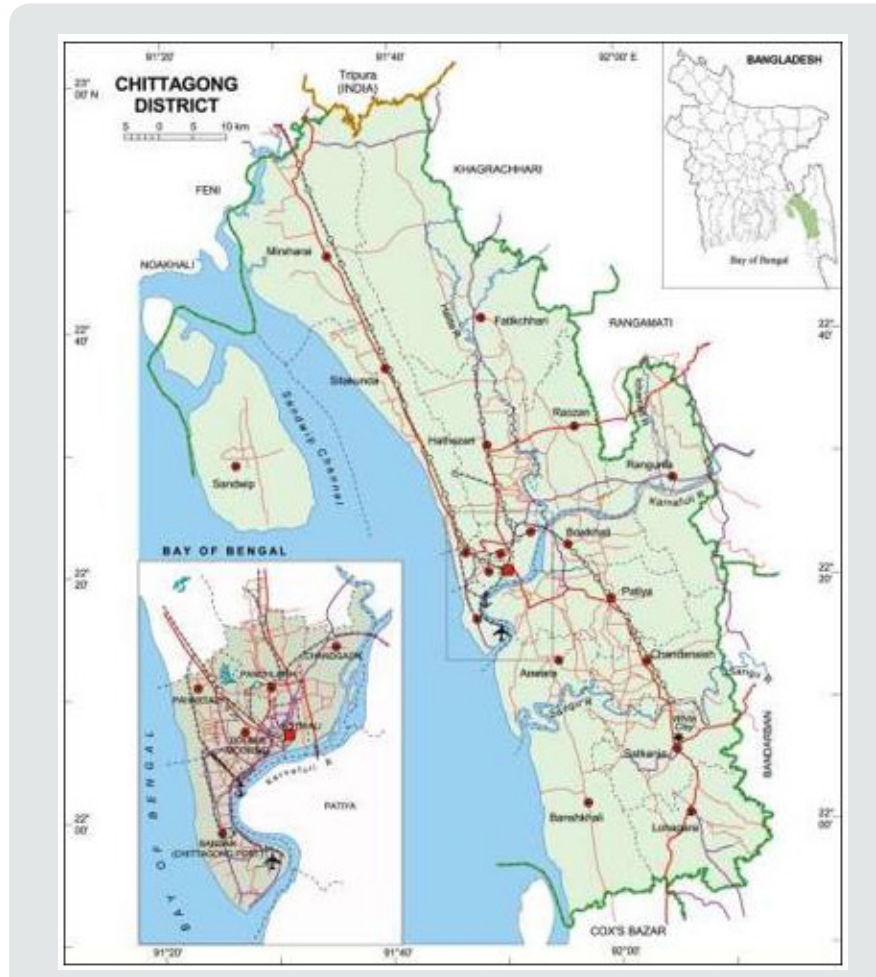

Figure 1: Site Location. Source: Mapofbangladesh.blogspot.in.

\section{Preference between apartment and land}

To purchase a land and then construct own building is preferred because there is feeling of security with the ownership, but the land prices are high and makes it unaffordable to most. Khaled et al. [1] 
survey report shows, the majority of the customers (70\%) prefer to buy an apartment as no construction hassle is there and also it saves time. However, $37 \%$ consumers prefer to purchase a land and construct their own building. Khaled, Sultana, Biswas, \& Karan [1].

\section{Review of rehabilitation schemes in Bangladesh}

\section{Bhashantek rehabilitation project}

From the field survey of three residential projects in Chittagong, the construction cost of high-rise buildings (more than six storied) is found to be approximately 2000 taka/sft and for low-cost housing, it is around $1200-1300$ taka/sqft.

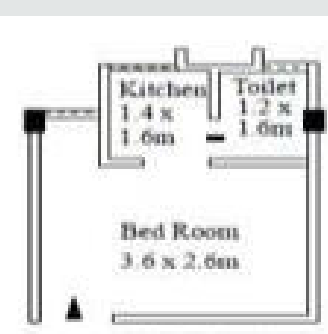

$1.2 \mathrm{~m}$ Wide Corrider Type-A for SDs

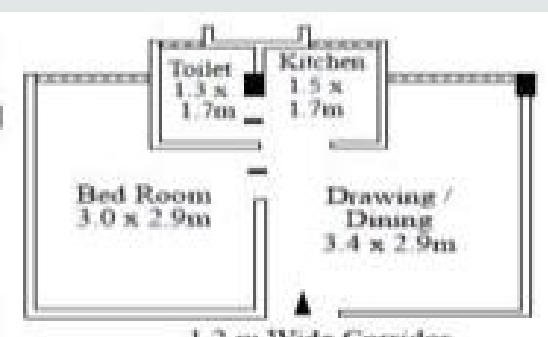

$1.2 \mathrm{~m}$ Wide Corrides

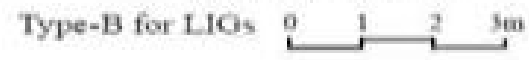

Figure 2: The types of unit plan in the Bhashantek Rehabilitation Project.

It is a public-private partnership project undertaken in 1998 by the government to provide housing for the Slum Dwellers (SD) and Low Income Group (LIG), The project was expected to provide shelter to more than 80,000 urban poor (Figure 2). This project was the first joint venture rehabilitation project by the Government and private organization in Bangladesh. Mohit [11] summary of Project: Total land area $=20$ hactor, apartment units are $=15024$. Residential land coverage is about $58 \%$ of total land. The government is providing the total land costs about US\$ 50 million. The selling price of apartment units is US\$160 per sqm. SDs flat= US $\$ 3000$ and for LIG it is = US $\$ 4480$.

\section{Design}

The Project consists of Six Storied Buildings, with Type A for SDs=18.75sqm; (60\%) and Type B for LIG=28.00sqm (40\%) (Figure 2). There are two types of unit plan in Bhashantek Rehabilitation Project Figure 2. Type A for slum dwellers (SD) and the type B for low income group (LIG) people respectively. The project failed to accommodate the target population due to flawed policy and the prices fixing beyond the affordability of the target population.

\section{Housing Project Case Study 01}

CDA Site and Service Residential Kolpolok project is at Bakolia area by the side of Sahamanat Bridge connecting Road. The total land area is 174 acres. The minimum size of Plot is 2.5 Katha, and maximum is 4.0 Katha (Table 4). The land acquisition Cost per Katha is 2.82lak taka (Tk), and land development cost is 68 thousand taka per Katha. So, the total cost per Katha is 3.5lak. This is also beyond the affordability limits of the target group. (Note: One US\$=Tk. 85; One million=10Laks; 1 Katha=67sq.m).

Table 4: Detailed land use schedule of the Kolpolok Residential Project.

\begin{tabular}{|c|c|c|}
\hline Sl. No & Description & \% \\
\hline & Residential area (A) & 60.81 \\
\hline & $\begin{array}{c}\text { Commercial and Community } \\
\text { area (B) }\end{array}$ & 38.361 \\
\hline & other areas (C) & 0.829 \\
\hline
\end{tabular}

\section{Housing Project, Case Study 02}

Total land area of the site and service project is above 170 acres where $57.75 \%$ area is used for residential plot, and 6.19\% land area for commercial purpose and detail percentage of land use is shown in the Table 5. The total cost of the project is 3976761000 taka where the cost per Katha is 386656 taka (Table 5). But here the Oxygen and Kulgaon Road construction Included and for that the development cost of the project increased. The price of the plot is 6 lakh taka per Katha. According to the price per Katha the minimum Plot (3.00 Katha) price is 18lak and Maximum plot 6.00 Katha) is 36Lak (Figure 3) \& (Table 5). 


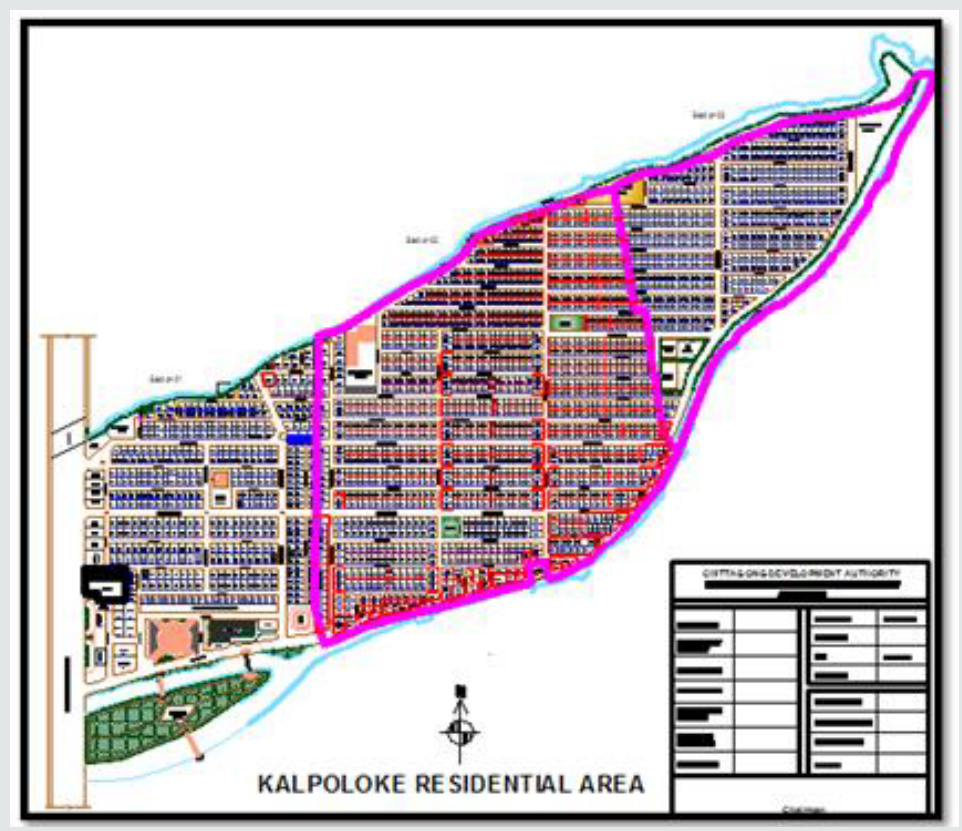

Figure 3:

Source: Chittagong Development Authority

Table 5: Cost of the Case Study project 02.

\begin{tabular}{|c|c|c|c|}
\hline SL No & Description & Anoyanna Housing Project in Tk. & UNIT \\
\hline 1 & \multirow{3}{*}{ Land Acquisition (Land Cost) } & 2211300000 & $\mathrm{Tk}$ \\
\hline 2 & & 13007647.06 & Tk/Acres \\
\hline 5 & & 215002.43 & Tk/Katha \\
\hline 7 & \multirow{3}{*}{ Land Development Cost } & 1765461000 & Taka \\
\hline 8 & & 10385064.71 & Tk/Acres \\
\hline 11 & & 171653.96 & Tk/Katha \\
\hline 13 & \multirow{3}{*}{ Total } & 3976761000 & Taka \\
\hline 14 & & 23392711.76 & Tk/Acres \\
\hline 17 & & 386656.39 & Tk/Katha \\
\hline
\end{tabular}

\section{Analysis of Selected Site}

In the site analysis, two important issues are focused:

a. The site surroundings, environments, and Land use of the site for housing and

b. The special potentiality of the site for the Rehabilitation of the landslide affected people for that site. None of the case studies seem to satisfy the target group affordability and spatial needs.

\section{Brief Description of Site}

According to Detail Area Plan (DAP,) 2008, a new township named Fathenagar New Township (FNT) was recommended in the zone DPZ 08 which is located at Hathazari and Raozan thana (North Chittagong) by the Hathazari Road and near Chittagong University, with a total area of 4700 acres where 2000 acres is reserved for the forest. It is connected to the City by Hathazari Road (N106) to the main city and by Nazirhat-Sholoshahar Railway. There is a different residential area for a housing project in the master plan and one site of around 42.16 acres is selected based as the demo study (Figure 4) \& (Map 1). 


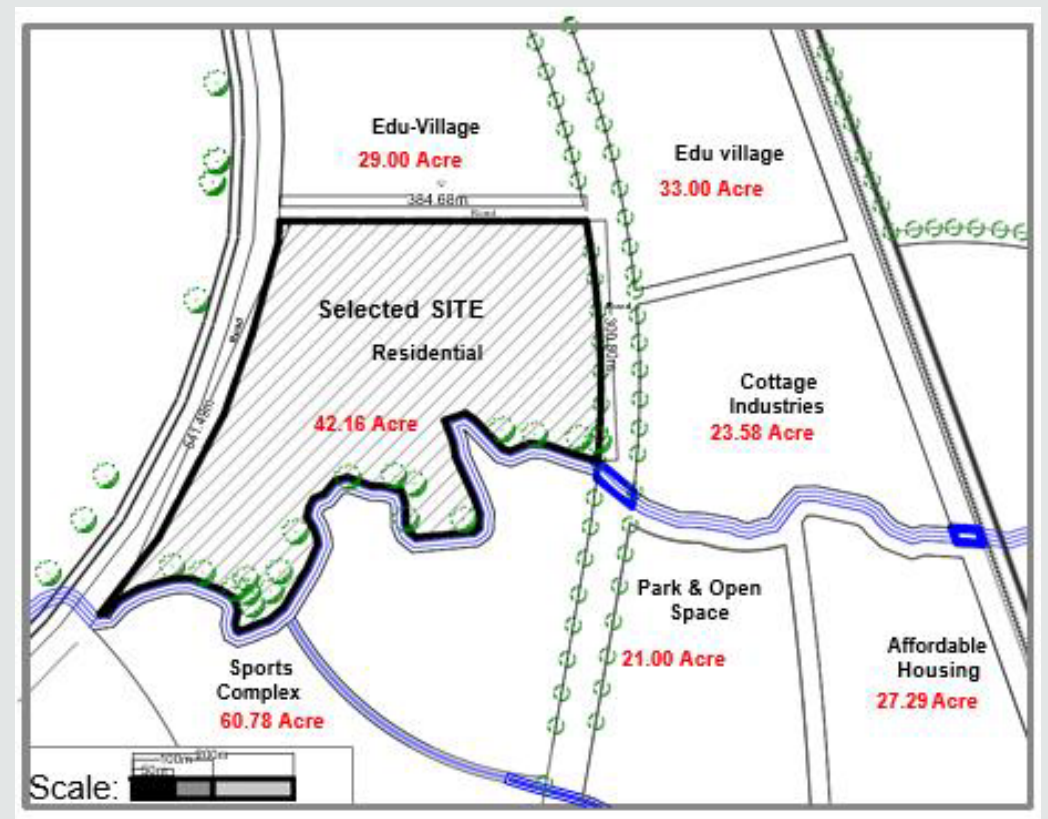

Figure 4: Site Plan with adjacent land use.

Source: Chittagong Development Authority.

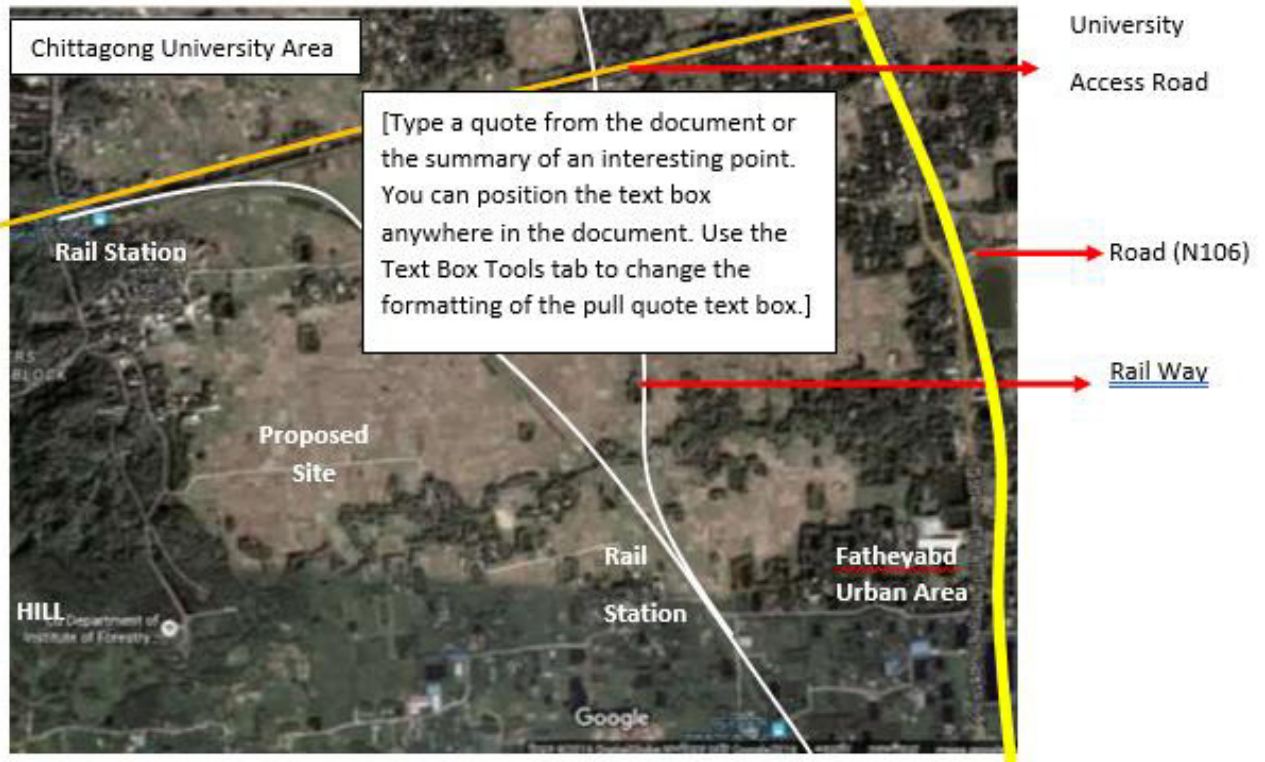

Map 1: Location of the Site.

Source: Map from Google Earth.

\section{The site}

1. It is located at DPZ 08 zone of Chittagong DAP, and the area is defined as residential area in DAP

2. It is located at New Township area which is a proposal of CDA.

3. It is expected to be safe from natural disaster likelandslide, flood, and cyclone.
4. Good communication to the main city by Rail and Road. The nearest railway station is only $15 \mathrm{~min}$ walking distance.

5. Landslide effected EWS people can go to their job easily by train which is cheaper and economically viable.

6. The market, school, and College are available in Fateyabad which is very near to the site. 


\section{Road network}

The new site is just by the side of Hathazari Road (N106) which is an important national road and directly link with the city. Local bus and other transports are available, and the travel time is around half an hour.

\section{Railway network}

According to the master plan of the new township there is circular Rail track which will provide mass transport for those inhabitants. From Fatheyabad to Sholoshahar (Main City), the travel time is 20 minutes, and the fair is also low (05 taka) and affordable (5-7\% of their income) for the poor people (Figure 4 \& 5).

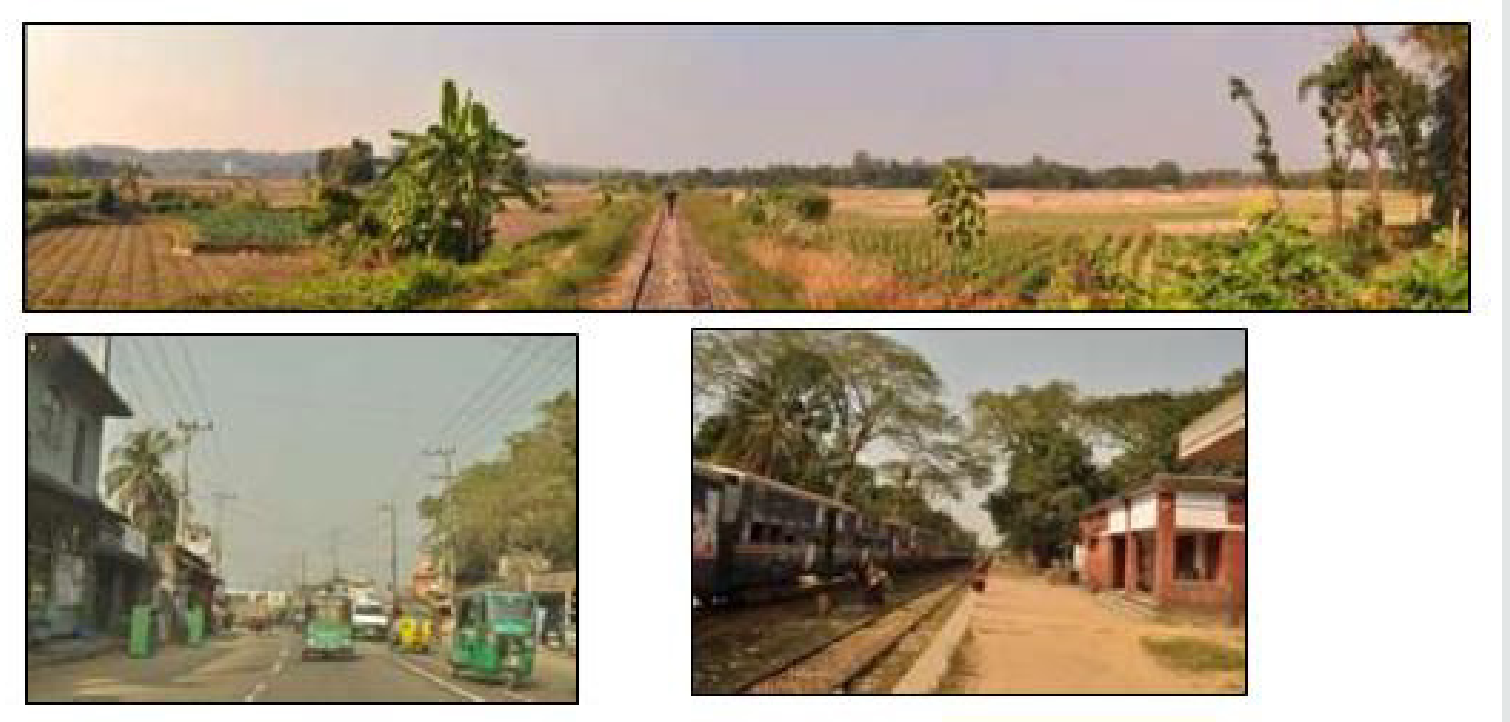

Figure 5: View of the site, Hathazari Road, and Fateyabad Rail station.

Source: Field Survey.

\section{Transport and communication}

The site is connected to the city by Rail and Road. The following Charts Show the Distance and Fair of Bus and Rail from City to the site.

\section{Economically feasibility analysis}

From the primary survey, it is found that the monthly family income is around 8000 to 9000 taka, and they can spend 2500 to 3000 taka (30\% of income) for housing of the informal sector of Chittagong. For special program from the government, they can get 2.5 to 3 lakh taka loan for housing. So, the price of the home should be up to 3 lakh Taka. The Bhasantek Gov Hosing project shows, the floor area required is about 200sft (18.5sqm). According to the housing policy land can be provided to the target people free. If the rehabilitation is a part of a normal housing, then the urban facilities and other areas can be shared which reduce the land development cost of that people, and the same time the

Table 6: Fair of bus and Train from City to the proposed site. total cost comes down. On the other hand, the construction cost of the building has to be minimum with minimum architectural and structural requirements. Considering housing project for informal sector as a part of housing the cost of the unit is almost 3 lakh taka. If the rehabilitation project has to be taken individually then the Land Acquisition cost which has considered as free will be almost 84000 (in combine project it is only 34800 taka) taka per family, and it is a great burden for the government. On the other hand, total unit cost will be more and if the facilities like school and clinic will be provided separately. If separate Plot is provided then only for aunit, (unit area 22.3sqm, Plot area 34sqm) the land acquisition cost is 1.5 lakh which is more burdain for government to give it free per family. Again, land development cost is 0.85 lakh, and Building cost is 2.9 lakh which is not affordable for the poor people and the plot size also too small to build separate building. In this way the poor people can get a shelter with free land where maximum family will share the land according to their demand and within present building construction rules (Table 6).

\begin{tabular}{|c|c|c|}
\hline Muradpur to Fateyabad (11 Km) & Bus/ Minibus & Local: $\mathbf{7 ~ T a k a ~}$ \\
\hline Rail Station & Distance & Fair \\
\hline Chittagong Central to Fateyabad Jn & 19Km & 6 Taka \\
\hline Sholoshahr Jn to Fateyabad Jn & $12 \mathrm{Km}$ & 5 Taka \\
\hline
\end{tabular}




\section{Proposal of Housing Scheme for Low Income People}

\section{Conceptual layout plan}

The main concept of the proposed layout housing plan is to create a central open space with facilities like playground, park, etc. which would be open to the south to enjoy the wind flow from south direction. Hierarchies of open spaces in the different residential zone are provided which can be gathering play space for local different age groups.

\section{Land use}

The housing colony is proposed with different land use where the maximum percentage of area is residential. The Educational, recreational uses are proposed at the centre of the colony. Other land uses such as Commercial (Kitchen Market and Shop), Community (Community Center and Mosques) and Clinic (Health facilities) are proposed at the edge of the site.

\section{Residential zoning, FAR, and height}

In the colony zoning is proposed according to a different type of consumers. The housing for poor people is separate from the general residential area. The area is divided into three part and the buildings are proposed by using MGC with the maximum floor is six (Ground +5). The 2.5 and 3.0 Katha plot are mainly for lower income and middle-income group, for that, these types of plot are proposed in a residential zone. On the other hand, 4.0 Katha is for higher middle class and 5.0 kata is for higher income group. The apartment block also is in the different residential zone with FAR 5.25 and the floor number is 13 (Ground +12 , with MGC 50\%). Here basement floors may be required for parking and ground floor is also considered for parking which are not FAR included.

\section{Proposal for poor people}

For the Rehabilitation people, the main aim is to provide safe shelter with minimum cost. At the same time the community demand, rules and regulation, requirements, environmental issues also have to be considered.

\section{Land area and land use}

Considering the total unit number of family around 2100 the total area for Landslide-affected people is around 5 acres including road, nursery school/children play area and community center. Here the residential use is 3.5 acres, and the floor area is on the base that land area. The Ground Coverage not more than $60 \%$ and the Minimum distance of two building is 5 meters (as per rules minimum distance 4.25 meter). Other urban amenities like market, health and School have to be shared with General housing scheme (Plan 1).

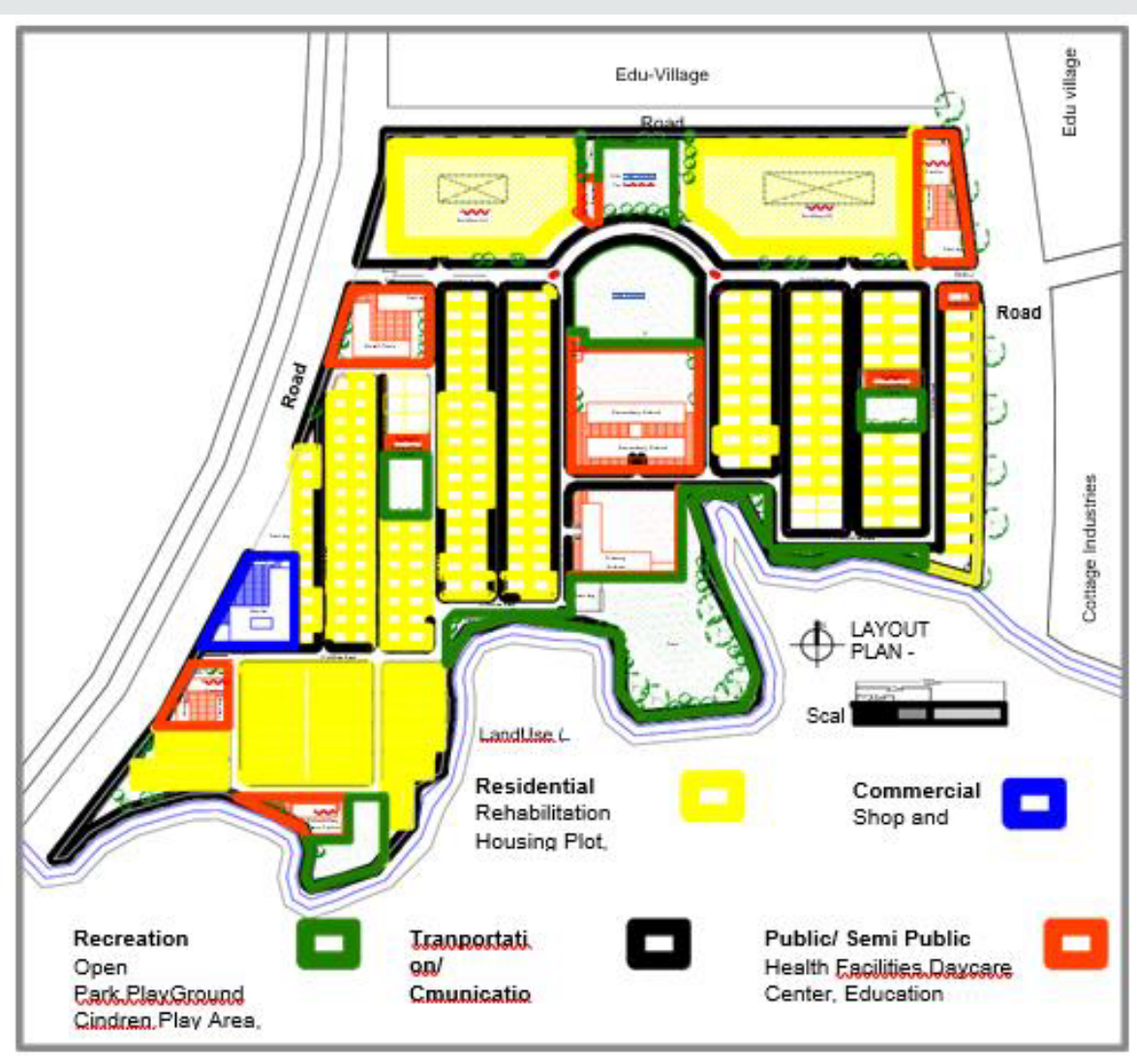

Plan 1: Land use proposal of the Scheme. 


\section{Built-up area and use of floor}

Considering the survey and Gov. Rehabilitation project at Mirpur Dhaka, the floor area is 240 sqft or 13 sqm and the maximum floor no is 5. No use of lift which increases the construction and maintaining cost. The building is proposed with a double-loaded corridor with minimum two stairs to minimize the service area of the building. In ground floor, the built-up area is 50\% use for house and rest $50 \%$ would be vacant (no wall) for bicycle/motorbike parking, socio-economy activity for that people. According to Building construction act the maximum FAR is 5.25 (with MGC 50\%) but taking the lower value of FAR the MGC is $65 \%$. Considering MGC is 60 to $63 \%$ and actual taking Far 3.25 to 3.50 . The total floor no is 5.5 (FAR included), the total floor area for Housing unit is around 43600sqm.

\section{Proposal for housing for general people}

In a housing project Plotted development and apartment are the main two types for residential projects. From literature review, it can be stated that the demand of apartment is more in Chittagong and on the other hand according to case study plot is still in demand. So here the project is a combination of Plot and apartment for residential use. Though $60 \%$ land is for the plot but according to FAR the total floor area is 158763 sqm but the house unit number is 1200 and $40 \%$ land for an apartment with floor area $187033 \mathrm{sqm}$ (base on FAR) where the house unit number is 1550. Detail of Plot and apartments' calculation are described below (Plan 2).
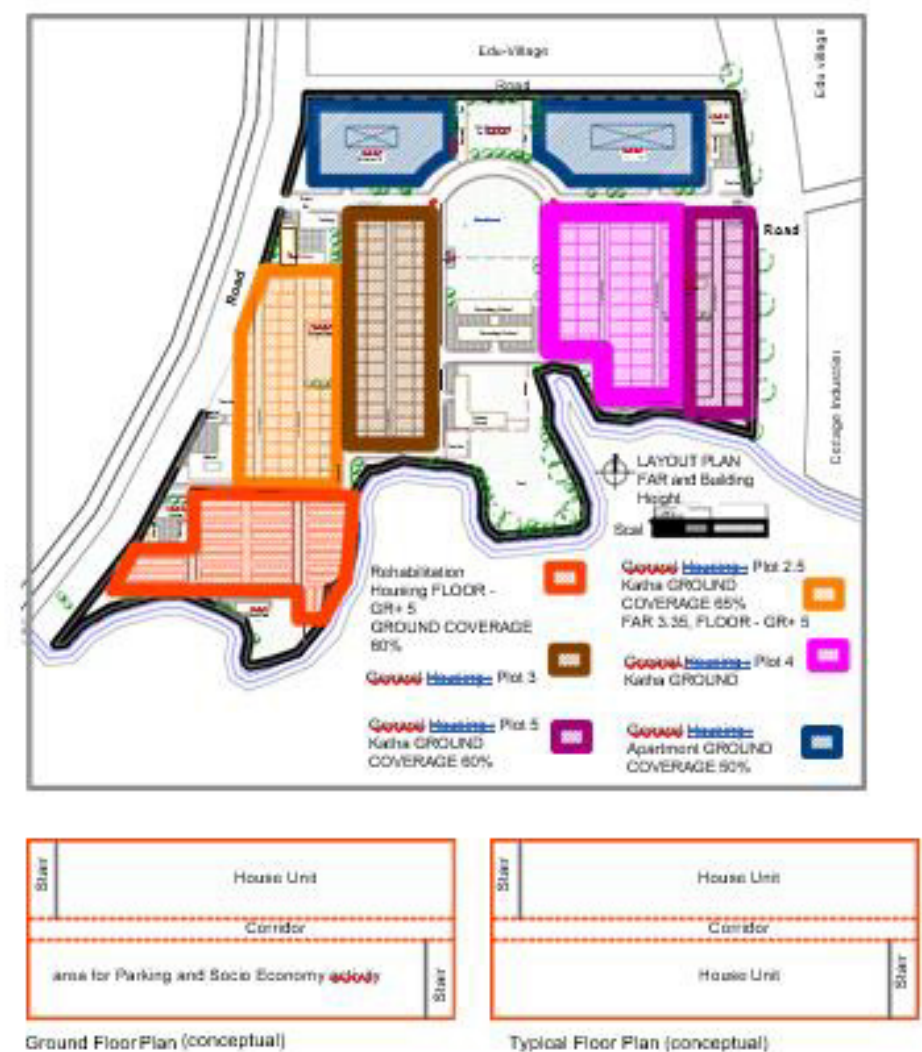

Plan 2: Residential Zoning, FAR, and Number of Floor of the Scheme.

\section{Land area and types of plot}

The total land area for the plot is 11.17 acres which are almost $59.8 \%$ of the residential area. The plots are mainly four types according to its area. The unit of area is Katha and one Katha are 720 sqft. The flowing tables show the percentage and number of different types of plot (Table 7-9).

Table 7: Different type of Plot a) percentage and Cost b) size of plots.

\begin{tabular}{|c|c|c|c|c|c|c|}
\hline \multicolumn{7}{|c|}{ Calculation of Different Type of Plot } \\
\hline \multicolumn{7}{|c|}{ Plot } \\
\hline \multirow{2}{*}{ S1 No } & Description & Type 1 & Type 2 & Type 3 & Type 4 & Unit \\
\hline \multirow{2}{*}{1} & \multirow{2}{*}{ Size } & 2.5 & 3 & 4 & 5 & Katha \\
\cline { 2 - 7 } & & 167.29 & 200.74 & 267.66 & 334.57 & Sqm \\
\hline
\end{tabular}




\begin{tabular}{|c|c|c|c|c|c|c|}
\hline 2 & Percentage of Plot & $19.17 \%$ & $34.51 \%$ & $30.10 \%$ & $16.22 \%$ & $\%$ \\
\hline 3 & Total area of Plot & 8698.9 & 15658 & 13650.6 & 7360.6 & Sqm \\
\hline 4 & Number of Plot & 52 & 78 & 51 & 22 & nos \\
\hline
\end{tabular}

Table 8: Percentage of Different type Apartment.

\begin{tabular}{|c|c|c|c|c|c|}
\hline Description & Type 1(LIG) & Type 2 MIG & Type 3 MIG & Type 4 HIG & Unit \\
\hline \multirow{2}{*}{ Size } & 850 & 1250 & 1500 & 1700 & sft \\
\cline { 2 - 6 } & 79 & 116.17 & 139.41 & 35.99 & Sqm \\
\hline Percentage of Apartment & 20 & 25 & 20 & 64611 & Sqm \\
\hline Total Floor Area & 36921 & 46151 & 36921 & 409 & No \\
\hline Number of Apartment & 467 & 397 & 265 & & \\
\hline
\end{tabular}

Table 9: Population Calculation.

\begin{tabular}{|c|c|c|c|c|c|c|}
\hline SI No & \multicolumn{2}{|c|}{ Description } & $\begin{array}{l}\text { Household Area } \\
\text { (In sqft) }\end{array}$ & $\begin{array}{l}\text { Household } \\
\text { Number }\end{array}$ & $\begin{array}{c}\text { Population / } \\
\text { Household }\end{array}$ & Population \\
\hline 1 & $\begin{array}{c}\text { Informal Sector } \\
\text { People }\end{array}$ & 240 & 2179 & 5 & 10896 & \\
\hline \multirow{5}{*}{2} & \multirow{5}{*}{ Plot } & Type 01 & 1000 (Assume) & 314 & 4.5 & 1411 \\
\hline & & Type 02 & 1400 (Assume) & 421 & 4.5 & 1895 \\
\hline & & Type 03 & 1600 (Assume) & 321 & 4.5 & 1446 \\
\hline & & Type 04 & 1800 (Assume) & 165 & 4.5 & 743 \\
\hline & & Total & & 1221 & & 5495 \\
\hline \multirow{5}{*}{3} & \multirow{5}{*}{ Apartment } & Type 01 & 850 & 467 & 4.5 & 1788 \\
\hline & & Type 02 & 1250 & 397 & 4.5 & 1192 \\
\hline & & Type 03 & 1500 & 265 & 4.5 & 1840 \\
\hline & & Type 04 & 1700 & 409 & 4.5 & 1840 \\
\hline & & Total & & 1538 & & 4820 \\
\hline 4 & \multicolumn{5}{|c|}{ Total Population people for general Housing } & 10315 \\
\hline
\end{tabular}

\section{Details area calculation for apartment}

The total land area for apartment is 7.6 acres, and there four type apartments are considered according to the demand of apartment in Chittagong. In the proposed scheme, the minimum apartment size is $850 \mathrm{sqft}$ (79sqm), most demandable area is 1250 to 1500 sqft ( 116.17 to $139.41 \mathrm{sqm}$ ) and the maximum apartment area is 1700 sqft (147.99sqm). This apartment size means the gross unit area which includes net unit area, lift, stair, lobby; corridor and others FAR included area. Far excluded areas like Veranda, Gardens are not included here. According to Building construction rules the playground is 0.76 acres $(10 \%$ of Land Area) and in the layout plan, it is proposed at the centre of apartment land area. The total apartment (residential use, FAR included) floor number is 12 Nos with using Maximum Ground Coverage (50\%), Ground floor is considered for parking and basement floor/floors also proposed for parking which are FAR excluded.

According to FAR chart, the value of FAR is 6.00 then the Total floor area is 184600sq.m and the following Table 8 show the detail calculation of FAR for of different types apartments. The urban facilities are an important issue for a successful housing project. The requirements of that area have to maintain in any housing projects. The percentage of saleable area is not more than $70 \%$ and according to case study, the residential area is around 53 to $60 \%$. For education three types school area proposed which Nursery or day care center, Primary school, and Secondary School. Different Nursery or day care centers are proposed in different residential zones with playground. One primary and one secondary school are proposed at the center of the colony and students of that colony are enough for that school (30\% of total population). Two community centers with the mosque (considering 90\% populations are Muslims) and Market with parking are located at the periphery of the site where outside people can join. A Central Playground for all at the center of the layout plan and a Park is suggested at the south part of the site by the bank of the cancel (Figure 6). 


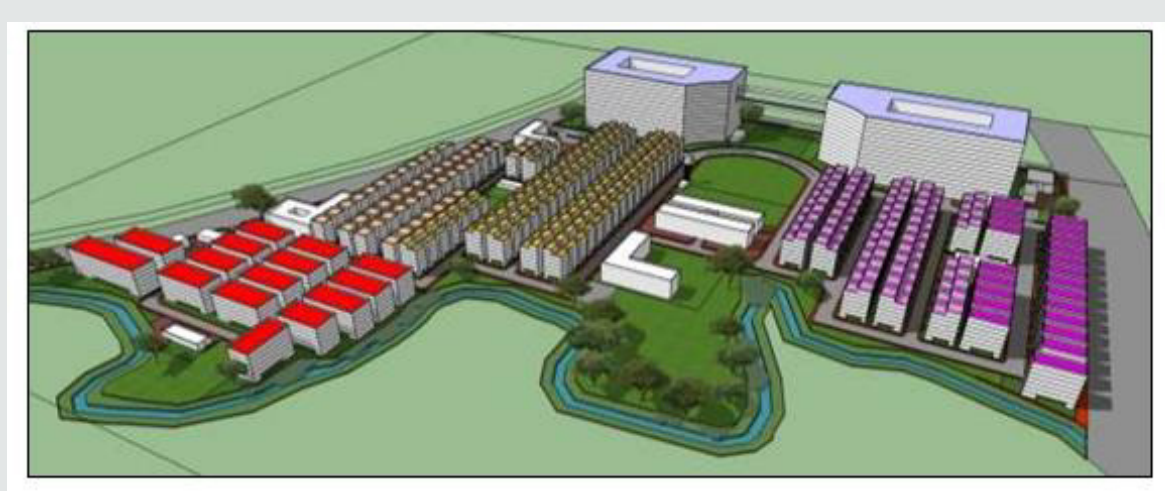

Figure 6: 3D view of the proposed Housing Scheme.

\section{Project Summary}

The proposed project is a composite housing scheme where different residential areas are proposed for a different type of people. According to the land area, almost $12-13 \%$ area used for the informal sector vulnerable people. On the other hand Plot and Apartment for the general people of Chittagong where according to the number of Household apartment type is more and according to land area Plot area is more but considering FAR and unit number of the household of Plot and Apartment almost same (Plot 44\% and
Apartment 56\%). Affordability of housing is the most important challenge for the poor people in any urban area. As from the survey the monthly income of the household is approximately 80000 to 90000 taka and from the literature review, 25-30\% amount of income can be a deposit for shelter. They can get a loan of up to 3 lakh taka based on their savings per month. So, it is economically viable for that poor people. The general housing (both from Plot and apartment), is also a profitable venture by assuming the present minimum price of plot and apartment (Figure 7).
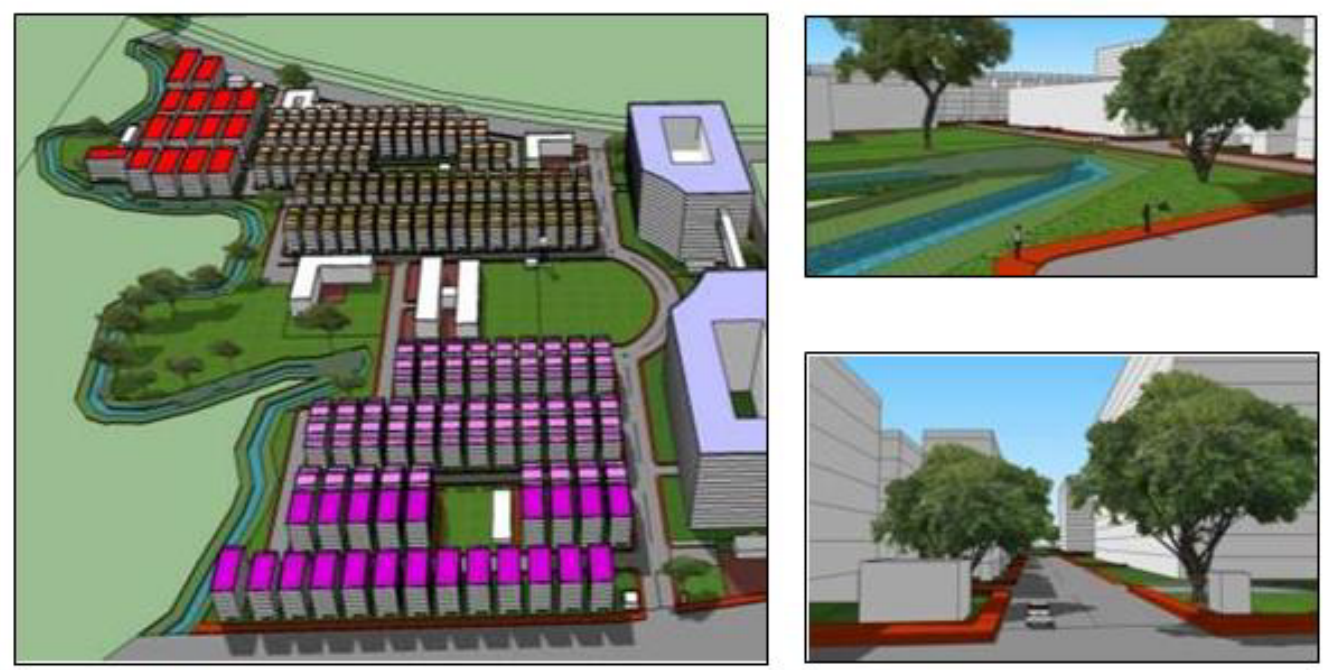

Upper View: From North Side, Lower left view: From East side. Lower right: Entry and Park

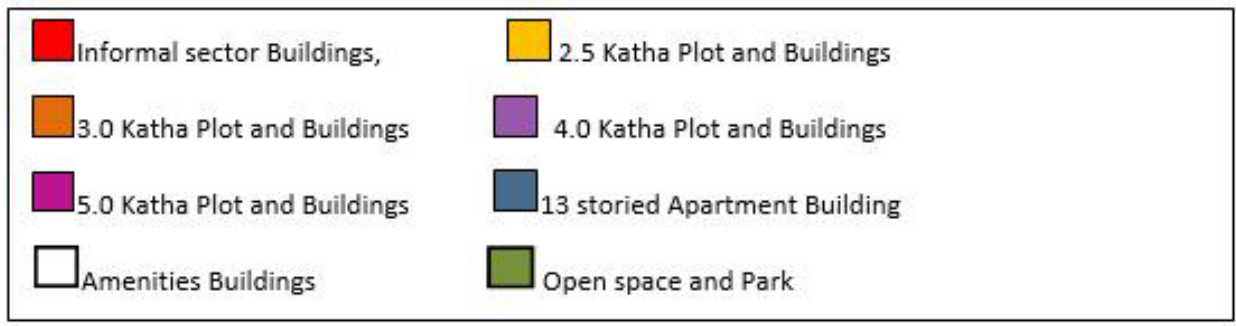

Figure 7.

Citation: Qazi Azizul Mowla, Kanu Kumar Das. Informal sector housing Scenario Analysis for Chattogram, Bangladesh: A Way Forward. Tr 
Table 10 In Plot, more profit is proposed for the five Katha which is mainly for the upper middle and high- income group, and they will get more FAR benefit also. On the other hand, three and four Katha plots are meant for the middle-income group which is with moderate profit and 2.5 kata are special consideration for the lower income group people with less profit. Again, four types apartment are proposed in the project where the largest area is 1700 sqft (158sqm) for HIG people with maximum profit. Another two-type apartment which area is 1250 sqft (116.1sqm) to 1500 sqft (139.4sqm), is proposed for MIG and the profit also is in moderate range and less than the market price of the apartment. Here apartments also proposed for the LIG people with 850sqft (79sqm) and the profit is also lowest. Finally, the project is expected to be successful where the profit is $164,68,75653$ taka (average $31.24 \%$ ). The investment and the Bank interest are not calculated.

Table 10: Total Cost and Profit of the Scheme.

\begin{tabular}{|c|c|c|}
\hline Total Cost for Plot & $\mathbf{5 . 3 5 E + 0 8}$ & Taka \\
\hline Total Cost for Apartment & $3.96 \mathrm{E}+09$ & Taka \\
\hline Total Cost for Rehabilitation & $7.79 \mathrm{E}+08$ & Taka \\
\hline Total Cost of The Project & $5.27 \mathrm{E}+09$ & Taka \\
\hline Total Income from Plot & $6.64 \mathrm{E}+08$ & Taka \\
\hline Total Income from Apartment & $5.57 \mathrm{E}+09$ & Taka \\
\hline Total income of rehabilitation & $6.82 \mathrm{E}+08$ & Taka \\
\hline Total Income the Project & $6.92 \mathrm{E}+09$ & Taka \\
\hline Total Profit & $1.65 \mathrm{E}+09$ & Taka \\
\hline Percentage of Profit & 31.24 & $\%$ \\
\hline
\end{tabular}

\section{Calculations}

In the housing policy, the government has committed to provide housing for all including the poor of the informal sector. Detail planning is required where all categories of people are addressed for housing. There are so many problem and limitations to provide housing for the target group and the main problem is affordability.
If individual housing project is prepared for them, then the price of plot or apartment would be high and beyond their affordability. In a combined housing scheme, the price of the house can bring within their buying capacity considering the land to be free to them. The proposed scheme where the land area is 42 acres, almost 2000 poor family can be relocated where the transportation, job and other basic demand can be fulfilled. This type of scheme can be applicable for the housing of all kind of informal sector people including the vulnerable people all over Bangladesh.

\section{References}

1. Khaled MC, Sultana T, Biswas SK, Karan R (2012) Real Estate Industry in Chittagong (Bangladesh): A Survey on. ISTE, Developing Country Studies 2(2).

2. NHA (2017) National housing policy. Dhaka: Bangladesh Government, Ministry of PWD and Housing.

3. Islam N (1990) Housing in Bangladesh an overview. Journal of Bangladesh Institute of Planners 1(1\& 2): 37-45.

4. Mowla QA (1999) Khulna's Urban Poor and Their Living Environment: A Point to ponder at the beginning of third Millennium, Khulna University Studies 1(2): 205-212.

5. Jamil GM, Ahmad M (2006) Housing for Low Income People in Bangladesh: Problems and Prospects. The Cost and Management 34(5): 25-39.

6. Islam N (2005) Dhaka Now: Contemporary Urban Development, Bangladesh. Geographic Society, Dhaka.

7. Nawaz R (2004) Right to Shelter: Bangladesh. International ConferenceAdequate \& Affordable Housing for All, Toronto, pp 24-27.

8. Nenova T (2010) Expanding Housing Finance to the Underserved in South Asia: Market Review and Forward Agenda. World Bank Publications.

9. Ahmad S (2014) Housing demand and housing policy. Urban Studies Journal Limited, SAGE.

10. IDS (2007) Governance Screening for Urban Climate Change resiliencebuilding and Adaptation strategies in Asia: Assessment of Chittagong City, Bangladesh. Institute of Development Studies.

11. Mohit MA (2012) An Assessment of Policy Approaches Adopted to Deal with Bastee Settlements of Dhaka City in Bangladesh.
This work is licensed under Creative Commons Attribution 4.0 License

To Submit Your Article Click Here: Submit Article

DOI: 10.32474 /TCEIA.2020.04.000180

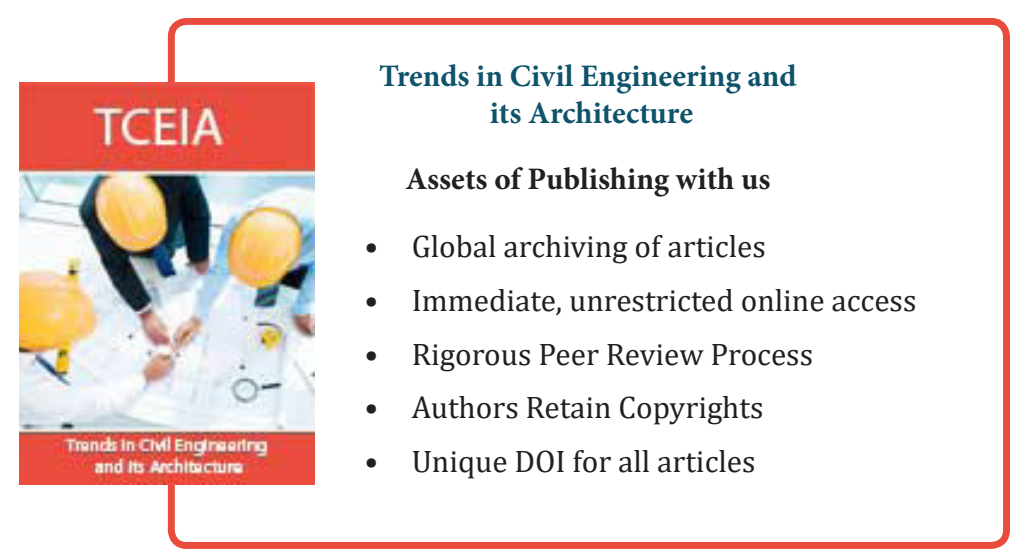

